\title{
A case study of Desmozoon lepeophtherii infection in farmed Atlantic salmon associated with gill disease, peritonitis, intestinal infection, stunted growth, and increased mortality
}

Simon Chioma Weli ${ }^{1}$, Ole Bendik Dale ${ }^{1 *}$, Haakon Hansen ${ }^{1}$, Mona Cecilie Gjessing ${ }^{1}$, Liv Birte Rønneberg ${ }^{2}$ and Knut Falk ${ }^{1}$

\begin{abstract}
Background: In September 2008, a disease outbreak characterized by acute, severe gill pathology and peritonitis, involving the gastrointestinal tract, was observed in an Atlantic salmon (Salmo salar L.) farm in north-western Norway. During subsequent sampling in November 2008 and January 2009, chronic proliferative gill inflammation and peritonitis was observed. Cumulative mortalities of $5.6-12.8 \%$ and severe growth retardation were observed. Routine diagnostic analysis revealed no diseases known to salmon at the time, but microsporidian infection of tissues was observed.

Methods: To characterize the disease outbreak, a combination of histopathology, in situ hybridization (ISH), chitin, calcofluor-white (CFW) staining, and real-time PCR were used to describe the disease progression with visualization of the D. lepeophtherii stages in situ.

Results: The presence of the microsporidian Desmozoon lepeophtherii was confirmed with real-time PCR, DNA sequencing and ISH, and the parasite was detected in association with acute lesions in the gills and peritoneum. ISH using a probe specific to small subunit 16S rRNA gene provided an effective tool for demonstrating the distribution of D. lepeophtherii in the tissue. Infection in the peritoneum seemed localized in and around pre-existing vaccine granulomas, and in the gastrointestinal walls. In the heart, kidney and spleen, the infection was most often associated with mononuclear leucocytes and macrophages, including melanomacrophages. Desmozoon lepeophtherii exospores were found in the nuclei of the gastrointestinal epithelium for the first time, suggesting a role of the gastrointestinal tract in the spread of spores to the environment.

Conclusions: This study describes the progression of D. lepeophtherii disease outbreak in an Atlantic salmon farm without any other known diseases present. Using different methods to examine the disease outbreak, new insight into the pathology of $D$. lepeophtherii was obtained. The parasite was localized in situ in association with severe tissue damage and inflammation in the gills, peritoneal cavity and in the gastrointestinal (Gl) tract that links the parasite directly to the observed pathology.
\end{abstract}

Keywords: Gut infection, Gill histopathology, Salmo salar L., Chitin staining, Calcofluor-white staining, in situ hybridization

\footnotetext{
* Correspondence: ole.b.dale@vetinst.no

${ }^{1}$ Norwegian Veterinary Institute, P.O.Box 750 Dep., N-0106 Oslo, Norway

Full list of author information is available at the end of the article
} 


\section{Background}

Atlantic salmon (Salmo salar L.) is the most important species for the aquaculture industry in Norway as well as in many other countries [1]. Atlantic salmon production in Norway suffers from several specific diseases that include pancreas disease (PD), heart and skeletal muscle inflammation (HSMI) and cardiomyopathy syndrome (CMS), all of which are characterized by chronic inflammation [2]. Chronic peritonitis is omnipresent due to the general use of oil-adjuvanted vaccines injected intraperitoneally, and this may also elicit autoimmune reactions [3]. Inflammation of the gastro-intestinal (GI) tract is seldom reported from farmed Atlantic salmon, but plant feed components used in brood fish production have been associated with an inflammatory bowel disease - colon cancer-like disease (IBD-CCD) [4]. Diseases affecting the gills are a growing problem in Atlantic salmon farming and several infectious agents have been associated with these diseases [5-7]. However, a lack of culture techniques and experimental models makes it difficult to identify primary pathogens, opportunistic and commensal agents in the plethora of microorganisms present in the gills [6-13].

Microsporidians are obligate, spore-forming intracellular parasites of vertebrates and invertebrates, including fish [14-18] and they are widely distributed in estuaries, sea and fresh water. They are thought to enter their host most often via the gut, injecting the sporoplasm into the host intestinal epithelial cells, spreading systemically by infected, circulating monocytes-macrophages [19, 20]. The spores shed to the environment are very resistant and complex life-cycles involving several host species occur, some even crossing the boundary of cold- and warm-blooded animals including humans [21]. Microsporidians known to cause disease especially in farmed salmonid fish comprise Loma salmonae, Nucleospora salmonis and Desmozoon lepeophtherii [19, 20]. In wild fish, Nucleospora cyclopteri has been shown to cause disease in lumpfish (Cyclopterus lumpus L.) [22]. Loma salmonae has a direct life-cycle, infects orally, and after hematogenic spread, xenomas form in the gills. When xenomas burst, a severe gill inflammation is incited that leads to significant disease losses in farmed, Chinook salmon (Oncorhynchus tshawytshca Walbaum) and rainbow trout (Oncorhynchus mykiss Walbaum) [19, 20, 23, 24]. Nucleospora salmonis infects a broad range of salmonid fish species and the replication takes place intra-nuclear especially in lymphoblast cells. In clinical cases of Chinook salmon and rainbow trout, anemia and a leukemia-like condition have been observed in which infected lymphoblast infiltrates many tissues and cause enlargement of the kidney, spleen and lower intestine [25]. The disease caused by $N$. cycloptera in lumpfish closely resembles the disease in salmonid fish caused by $N$. salmonis [22]. The
Nucleospora species are closely related to D. lepeophtherii, which was first described by Freeman and others as an infection of salmon sea lice (Lepeophteirus salmonis Krøyer) $[26,27]$ and later in Atlantic salmon [28]. In Atlantic salmon $D$. lepeophtherii has been reported using the junior synonymous name Paranucleospora theridion [27]. In sea lice, D. lepeophtherii form large xenomas and appear pathogenic to the sea lice [28]. In Atlantic salmon, $D$. lepeophtherii do not form xenomas, but two reproductive cycles have been described by Nylund et al. [29]. In the cytoplasm of leukocytes, macrophages, endothelium and epithelial cells of the skin and gill, many small autoinfective spores $(c .1 .0 \mu \mathrm{m})$ are produced and disseminated systemically. Another reproductive cycle takes place in the nucleus of epithelial cells of the skin and gill and results in a few, thick walled spores $(c .2 .0 \times 2.5 \mu \mathrm{m})$ that are presumably released to the environment [29]. In 2005, Kvellestad and co-workers [13] suggested that the etiology of proliferative gill inflammation (PGI) is multifactorial. In 2010, Steinum and co-workers [6] found that Atlantic salmon with severe PGI appear to have a higher load of $D$. lepeophtherii infection than non-PGI fish. A similar conclusion was reached in an extensive PCR screening of $D$. lepeophtherii infection in farmed Atlantic salmon suffering from a set of different disease conditions [10]. No clear correlation between the diseases and the levels of D. lepeophtherii infection was found, but the D. lepeophtherii infection was often present and could possibly aggravate the various disease conditions.

In the present study, we examined fish at three time points during a natural disease outbreak of a severe $D$. lepeophtherii infection, with the aim of addressing the lack of suitable in situ methods and D. lepeophtherii disease characterization. To do this, we used a combination of traditional histopathology, in situ labelling and PCR. By comparing the different methods for detection and characterization of D. lepeophtherii disease, we uncover new information about $D$. lepeophtherii disease pathogenesis.

\section{Methods}

\section{Fish sampling}

In August 2008, an acute disease problem started affecting fish with normal size and shape weighing about $400 \mathrm{~g}$ on the average. The farm is located within a fjord and the nearest representative location for environmental measurements operated by the Norwegian Institute of Marine Research (IMR) is Sognessjøen. In the relevant period of 2008, the measured monthly temperature was higher than normal. The measured temperatures at $1 \mathrm{~m}$ depth and the difference from corresponding historic averages from 1935 to 1993 were as follows: May: 11.1 (+2.9) ${ }^{\circ} \mathrm{C}$; June: $14.2(+2.5){ }^{\circ} \mathrm{C}$; July: $16.0(+2.0){ }^{\circ} \mathrm{C}$; August: 16.7 (2.3) ${ }^{\circ} \mathrm{C}$; September: $15.0 \quad(+2.0){ }^{\circ} \mathrm{C}$; 
October: $11.6(+0.9){ }^{\circ} \mathrm{C}$; November: $10.1(+0.9){ }^{\circ} \mathrm{C}$; December: $7.6(+0.4){ }^{\circ} \mathrm{C}$; and January $20096.1(-0.1){ }^{\circ} \mathrm{C}$. In a fjord system the surface water are influenced by fresh water and salinity fluctuate around 30\%. The salinity at Sognessjøen in 2008 was predominantly within the normal range around this value.

The 21 diseased fish chosen for further examination in this study were sampled in September 2008 (A1-7), November 2008 (B1-8) and January 2009 (C1-6). Tissue samples were fixed in $10 \%$ phosphate buffered formalin and RNAlater (Sigma-Aldrich, Hamburg, Germany) and submitted to the Norwegian Veterinary Institute Oslo for further diagnostic investigations.

\section{Verification of $D$. lepeophtherii by PCR}

A similarly-sized small piece of kidney and/or gill tissue was cut off and lysed overnight at $56{ }^{\circ} \mathrm{C}$ in $100 \mu \mathrm{l}$ of Mole $^{\odot}$ lysis buffer and $10 \mu$ l of Proteinase $\mathrm{K}$ solution (Sigma-Aldrich, Hamburg, Germany). DNA from each piece was then extracted on a GenMole (Mole Genetics, Oslo, Norway) using the Mole Genetics DNA Tissue Kit and the DNA tissue protocol. Approximately $900 \mathrm{bp}$ of rDNA was amplified using the primers and protocol of Freeman et al. [22] as described below. All PCR reactions were done using Illustra PuReTaq Ready-To-Go ${ }^{\mathrm{m}}$ PCR Beads (GE Healthcare, Oslo, Norway). Each reaction contained $1 \mu \mathrm{l}$ of the forward primer, $1 \mu \mathrm{l}$ of the reverse primer, $3 \mu \mathrm{l}$ of the template DNA and $20 \mu \mathrm{l}$ of sterile water. PCR products were sent to Macrogen for sequencing (Macrogen, Amsterdam, The Netherlands). All products were sequenced using the PCR primers. Sequences were proofread in VectorNTI ver. 11 (Invitrogen, Oslo, Norway) and subjected to a GenBank BLASTn search to search for identity with known sequences. The same samples were also subjected to RT-PCR analyses following the protocol of Nylund et al. [29], but targeting the rRNA gene and each analysis was repeated once. Average values for replicates were calculated.

\section{Histopathology}

The formalin-fixed tissues were paraffin-embedded and serial sections stained with hematoxylin and eosin (HE) according to standard histological techniques [30] and the in situ methods described below.

\section{Calcofluor White (CFW) method}

CFW staining was performed according to Monheit and others and Stine et al. [31, 32]. Briefly, paraffinembedded tissue sections were de-waxed in xylene, rehydrated through graded alcohols and washed in distilled water. Subsequently, slides were treated with a $10 \%$ $\mathrm{KOH}$ solution in distilled water for $2 \mathrm{~min}$ and stained with $0.05 \%$ Calcofluor white stain (Becton Dickinson, Franklin Lakes, USA) for $2 \mathrm{~min}$. The stained samples were immediately examined with epi-fluorescence microscopy for the presence of spores.

\section{Fluorescent chitin-binding probe (FCP) method}

The chitin-binding lectin probe made from chitinase A1 of Bacillus circulans was used for detection of $D$. lepeophtherii [33]. After de-waxing tissue sections in $\mathrm{xy}$ lene and rehydration through graded alcohols, sections were washed in distilled water and subjected to antigen retrieval by microwave treatment in citrate buffer solution (0.01 M, pH 6.0). Non-specific binding sites were blocked by incubation in $5 \%$ fetal bovine serum (FBS) for $20 \mathrm{~min}$ at room temperature. Fluorescein-conjugated chitin-binding lectin probe (New England BioLabs, Hitchin, UK) diluted 1:100 in PBS in 1\% FBS was then added onto each tissue section and incubated overnight in dark at room temperature. Sections were washed in PBS, mounted with SlowFade Gold anti-fade reagent (Invitrogen, Oslo, Norway) and examined by epifluorescence microscopy (Leica, DM5000B).

\section{In situ hybridization (ISH) method RNA isolation}

RNA from $D$. lepeophtherii-infected samples was isolated with Trizol ${ }^{\mathrm{TM}}$ reagent (Life Technologies Burlington, ON, Canada) and quantified using the NanoDrop ND-100 spectrophotometer (NanoDrop Technologies, Wilmington, USA). Desmozoon lepeophtherii was amplified using a SuperScript III Platinum One-Step Quantitative RT-PCR system. Total reaction of $50 \mu \mathrm{l}$ containing $1 \mu \mathrm{g}$ of total RNA, $25 \mu \mathrm{l} 2 \times$ reaction mix, $1 \mu$ l Platinum Taq enzyme and 10 pmol of primer sets (forward: 5'-GTC TGT GGA TCA AGG ACG AA-3'; reverse: 5'-ACT GAT ATG CTT AAG TTC AGG-3'; GenBank accession no. AJ431366) previously described by Freeman et al. [22], was used. The thermocycling conditions were $30 \mathrm{~min}$ at $60{ }^{\circ} \mathrm{C}$ reverse transcription, $3 \mathrm{~min}$ of denaturation step at $95{ }^{\circ} \mathrm{C}$ and 30 amplification cycles $\left(95{ }^{\circ} \mathrm{C}\right.$ for $30 \mathrm{~s}, 55^{\circ} \mathrm{C}$ for $30 \mathrm{~s}$ and $72{ }^{\circ} \mathrm{C}$ for $1 \mathrm{~min}$ ) and a $10 \mathrm{~min}$ elongation step at $72{ }^{\circ} \mathrm{C}$. PCR product of approximately $800 \mathrm{bp}$ was amplified and visualized in ethidium bromide-stained $1.2 \%$ agarose gel.

\section{Probe preparation}

The amplified PCR product was purified using the Nucleospin extract II (Macherey-Nagel GmbH, Düren, Germany), cloned into Escherichia coli cells (pGEM ${ }^{\circ}-\mathrm{T}$ Vector Systems; Promega, Fitchburg, WI, USA) and plasmid DNA was purified using Nucleospin ${ }^{\ominus}$ Plasmid (Macherey-Nagel GmbH, Düren, Germany). For verification of template, plasmid DNA with insert was sequenced with primers for D. lepeophtherii and M13 and D. lepeophtherii sequence downloaded from GenBank 
(accession no. AJ431366) was included in the alignment to verify the identity of $D$. lepeophtherii.

\section{Digoxigenin-labelled RNA probes}

Purified plasmid DNA was digested overnight at $37{ }^{\circ} \mathrm{C}$ with restriction enzymes HindIII and PvuII (Promega, Fitchburg, WI, USA). Probe-labelling was performed using DIG RNA Labelling kit (SP6/T7) as recommended by the manufacturer (Roche Diagnostics, Oslo, Norway) to generate DIG-labelled RNA anti-sense and sense probes, respectively. Labelled RNA was purified using illustra $^{\mathrm{mm}}$ probe Quant $^{\mathrm{mm}}$ G-50 $\mu$ columns probe purification kit (GE Healthcare, Oslo, Norway) according to the manufacturer's instructions.

\section{In situ hybridization}

Incubations were performed at room temperature unless otherwise stated. Serial sections were incubated with anti-sense and sense probes as positive and negative controls, respectively. Hybridization was performed according to Solstad et al. [34]. Briefly, tissue sections were equilibrated in DEPC-PBS, deparaffinised, rehydrated and permeabilized in $0.3 \%$ Nonidet P-40 (Roche Diagnostics, Oslo, Norway) in DEPC-PBS. Sections were digested in $10 \mu \mathrm{g} / \mathrm{ml}$ proteinase $\mathrm{K}$ in TE buffer ( $50 \mathrm{mM} \mathrm{HCL}, 5 \mathrm{mM}$ EDTA, pH 7.5) for $10 \mathrm{~min}$ at $37^{\circ} \mathrm{C}$, post-fixed for $10 \mathrm{~min}$ in $4 \%$ formaldehyde in DEPC-PBS and washed in DEPCPBS. Sections were acetylated in $150 \mathrm{ml}$ DEPC-water containing $750 \mu \mathrm{l}$ acetic acid anhydride and $2 \mathrm{ml}$ triethanolamine for $10 \mathrm{~min}$. Pre-hybridization was performed at $55{ }^{\circ} \mathrm{C}$ for $1 \mathrm{~h}$ in a humidified chamber with hybridization buffer containing $50 \%$ formamide, $2 \times$ SSC, $50 \%$, dextran sulphate $(w / v), 4 \mathrm{mg} / \mathrm{ml}$ Calf Thymus DNA, and $20 \mu \mathrm{l}$ 10x Denhardts solution. Hybridization was performed using $40 \mathrm{ng}$ anti-sense and sense probes as positive and negative control at $55{ }^{\circ} \mathrm{C}$ in a humidified chamber overnight. Washing was performed at $55{ }^{\circ} \mathrm{C}$ with $2 \times$ SSC, $1 \times$ SSC, $0.5 \times$ SSC, $0.1 \times$ SSC and TBS buffer $(0.1 \mathrm{M}$ Tris- $\mathrm{HCl}$, $\mathrm{pH} 7.5 ; 0.15 \mathrm{M} \mathrm{NaCl}$ for $5 \mathrm{~min})$. Immunodetection of the D. lepeophtherii probe was performed with alkaline phosphatase-conjugated anti-DIG Fab fragments (Roche Diagnostics) using Fast Red TR/Naphthol As-MX substrate (Sigma-Aldrich, Hamburg, Germany).

\section{Results}

\section{Case description including clinical, gross pathological findings}

The sea-water farm at the Norwegian west coast stocked the affected year class of Atlantic salmon smolts during spring 2008. The fish had been given intraperiotoneal injection with an oil-adjuvant vaccine. After sea-water transfer, the only health problem was the presence of some emaciated fish that was attributed to a previous outbreak of infectious pancreatic necrosis (IPN) during the freshwater stage. In August 2008, an acute disease problem started affecting fish in normal size and shape weighing about $400 \mathrm{~g}$ on average. The daily mortality was highly variable and from seawater transfer to the end of January 2009 the cumulative mortality ranged from 5.6 to $12.8 \%$ in the 8 net-pens involved. The clinically affected fish showed stunted growth and weighed $20-25 \%$ of normal growing fish by the end of January 2009. The clinically affected fish swam sluggishly, but responded with flight upon netting. They had stopped eating and the skin often appeared dark with a greenish hue. On autopsy the gills appeared uneven and with more mucus than normal. Some fish had small skin bleedings at the fin bases (Fig. 1). In the abdomen variable liver color, swollen spleen, ascites, hyperemia and often peritonitis as with high grade vaccination side effects were noted. Also a few fish had greyish, cheese-like enlarged kidney (Fig. 1).

\section{Real time PCR}

Kidney and/or gill samples from 20 fish from the 3 different samplings were analyzed and 20 out of 21 fish were positive for $D$. lepeophtherii (Table 1). From one fish (A2) there was no PCR result, but D. lepeophtherii was found with ISH. Sequences ( $800 \mathrm{bp})$ were obtained from most individual samples by conventional PCR. Apart from two ambiguous bases, the Blast search showed that the sequences were identical to $D$. lepeophtherii (AJ431366) confirming the identity of the parasite. Thus all fish were infected with $D$. lepeophtherii. Non-normalized PCR threshold cycles among tested samples ranged from 16 to 31 . The lowest

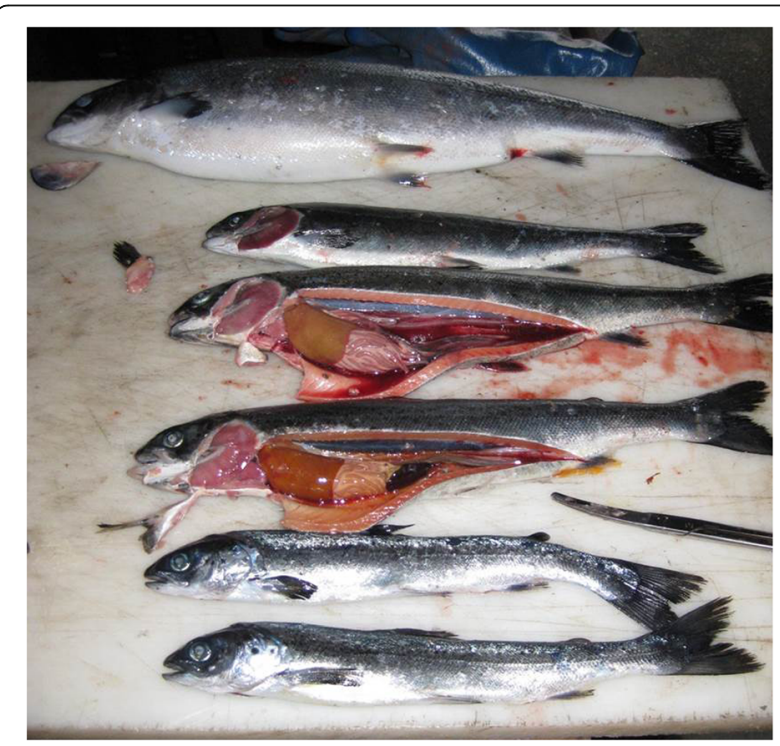

Fig. 1 Autopsy showing the degree of stunted growth: the fish on the top has grown normally 
Table 1 Comparing of semi-quantitative scoring of sampled fish tissues based on HE staining, calcofluor white staining and real-time PCR Ct-values

\begin{tabular}{|c|c|c|c|c|c|c|c|c|}
\hline \multirow{2}{*}{$\begin{array}{l}\text { Pathology scores } \\
\text { of each fish }\end{array}$} & \multirow{2}{*}{$\begin{array}{l}\text { Fish } \\
\text { ID }\end{array}$} & \multicolumn{3}{|c|}{ Histopathology scores } & \multicolumn{2}{|c|}{ Calcofluor staining scores } & \multicolumn{2}{|c|}{ Real-Time PCR Ct-values } \\
\hline & & Gill Microvesicles & PGI & Peritonitis & Gill & Peritoneum & Heart/Kidney & Gil \\
\hline Acute & A6 & 3.0 & 1.0 & 2.0 & 3.0 & 2.0 & 17 & nd \\
\hline Acute & $\mathrm{A} 1$ & 3.0 & 1.0 & 1.0 & 2.0 & 2.5 & 17 & nd \\
\hline Acute & A3 & 3.0 & 1.0 & 2.0 & 3.0 & 1.5 & 17 & nd \\
\hline Acute & A7 & 3.0 & 1.0 & 3.0 & 2.0 & 3.0 & 18 & nd \\
\hline Acute & A4 & 3.0 & 1.0 & 1.5 & 3.0 & 1.0 & 20 & nd \\
\hline Acute & B1 & 3.0 & 1.0 & 2.5 & 3.0 & 1.0 & nd & 20 \\
\hline Subacute & B2 & 3.0 & 2.0 & 1.5 & 3.0 & 1.0 & nd & 22 \\
\hline Subacute & A5 & 2.0 & 1.0 & 3.0 & 1.0 & 1.5 & 24 & nd \\
\hline Subacute & B3 & 2.0 & 2.0 & 3.0 & 1.5 & 3.0 & nd & 27 \\
\hline Subacute & $A 2$ & 1.0 & 1.0 & 3.0 & 1.0 & 0.5 & nd & nd \\
\hline Chronic & $C 2$ & 2.0 & 2.5 & 1.5 & 2.0 & 1.0 & 21 & 20 \\
\hline Chronic & B4 & 2.0 & 3.0 & 2.5 & 2.5 & 2.0 & nd & 23 \\
\hline Chronic & C4 & 1.0 & 2.0 & 3.0 & 1.0 & 1.5 & 26 & 24 \\
\hline Chronic & C3 & 1.5 & 2.0 & 2.0 & 1.0 & 1.0 & 28 & 25 \\
\hline Chronic & B8 & 2.0 & 1.0 & 2.0 & 1.0 & 1.5 & nd & 26 \\
\hline Chronic & $\mathrm{Cl}$ & 1.0 & 0.5 & 1.5 & 1.0 & 0.0 & 25 & 26 \\
\hline Chronic & C6 & 1.0 & 2.0 & 1.5 & 0.0 & 0.0 & 23 & 27 \\
\hline Chronic & B7 & 1.0 & 0.5 & 3.0 & 1.0 & 2.5 & nd & 28 \\
\hline Chronic & B6 & 1.0 & 0.5 & 2.0 & 1.0 & 0.0 & nd & 30 \\
\hline Chronic & B5 & 1.0 & 0.5 & 2.0 & 1.0 & 1.0 & nd & 30 \\
\hline Chronic & C5 & 1.0 & 1.0 & 2.0 & 1.0 & 1.5 & 26 & 31 \\
\hline
\end{tabular}

Abbreviation: nd not done

Ct-values were found in the first sampling. When relating the Ct-values to the pathology stages observed, the acute stage samples were represented by $\mathrm{Ct}$-values from 20 and below. The $\mathrm{Ct}$ values found in the non-acute stages were from 20 and above, with considerable variation and overlap between the sub-acute and chronic stages (Table 1).

\section{In situ detection methods with CFW, FCP and ISH}

Desmozoon lepeophtherii spores on HE were difficult to observe and appeared as unstained, iridescent granules (Fig. 2a). These observations were in contrast to FCP, which revealed many fluorescent spores in bright green (Fig. 2b) and bright blue with CFW (Fig. 2c). The FCP gave stronger signal that was easier to differentiate from the tissue background than CFW. In the cytoplasm, small $(c .1 \mu \mathrm{m})$ round, thin-walled spores in clusters were found that are regarded auto-infective. Fewer, larger $(c .3-4 \mu \mathrm{m})$ oblong spores was occasionally found, these are formed in the nucleus and released to the environment [29]. ISH did not react notably with spores, but reacted strongly with cytoplasmic and intra-nuclear round bodies of variable size often surrounded by a clear halo (Fig. 2d and f). No staining was observed with sense probes used as negative controls. The ISH stained bodies could be recognized as uniformly pink on HE-stained preparations, but stood out from the surrounding cytoplasm or nucleus only due to the halo. The stages stained by the rRNA probe may represent ribosome-rich stages like merogonia and plasmodia [29].

\section{Histopathology}

As expected in a natural disease outbreak the disease course and histopathological lesions were not synchronous in fish sampled at the same time point. However, there was a general progression from acute to chronic changes over time. We grouped and described the sampled fish according to their predominating histopathology as acute, sub-acute or chronic histopathology (Fig. 3).

\section{Overview of histopathological findings}

The acute group had necrosis especially in the gills and peritoneal cavity with severe, disseminated $D$. lepeophtherii infection that was as also found in most other organs studied. The number of D. lepeophtherii seen in the lesions was low in both sub-acute and 


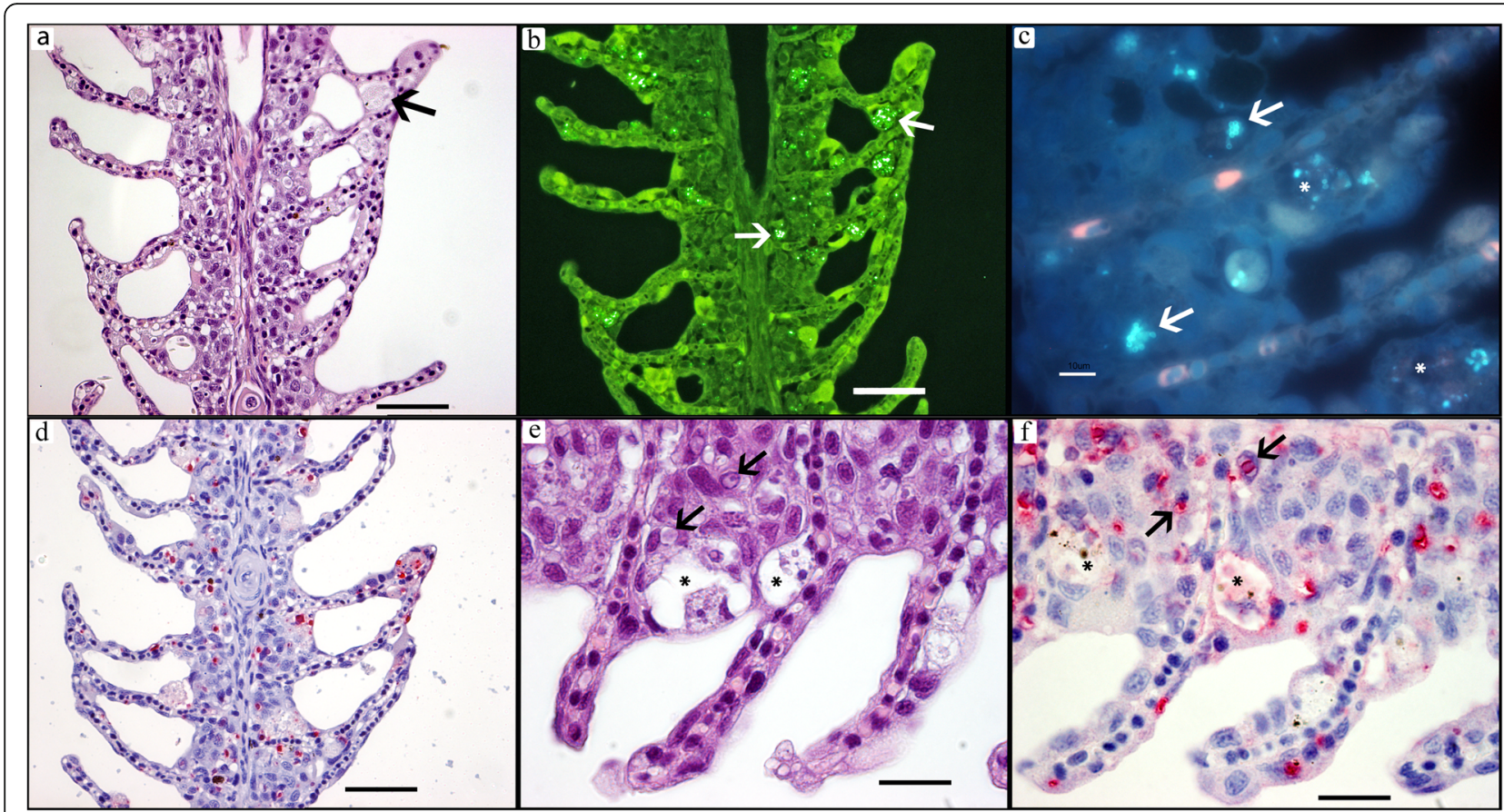

Fig. 2 Acute group: gill infection co-localized with necrosis. a HE-stain, distal adherences between slender lamellas with swollen, necrotic cells sometimes with poorly stained, iridescent D. lepeophtherii spore clusters (arrow). b FCP, green FITC chitin staining of D. lepeophtherii spore clusters (arrows) corresponding with the iridescent spores on HE-stain in a. c CFW, UV-blue chitin fluorescence of D. lepeophtherii spore clusters (arrows), necrosis $\left(^{*}\right)$. $\mathbf{d}$ ISH, rRNA probe staining proliferative stages of $D$. lepeophtherii red. e HE-stain, severely infected gill epithelium, swollen necrotic cells $\left({ }^{*}\right)$, cytoplasmic and intranuclear proliferative stages surrounded by a clear halo (arrows). $\mathbf{f} I S H$, same gill as (e), intense staining of the halo surrounded bodies in both cytoplasm and nucleus (arrows), less staining in necrotic cells often with some melanin granules $\left({ }^{*}\right)$. Scale-bars: $\mathbf{a}, \mathbf{b}, \mathbf{d}$ $50 \mu m ; \mathbf{c}, \mathbf{e}, \mathbf{f}, 10 \mu \mathrm{m}$

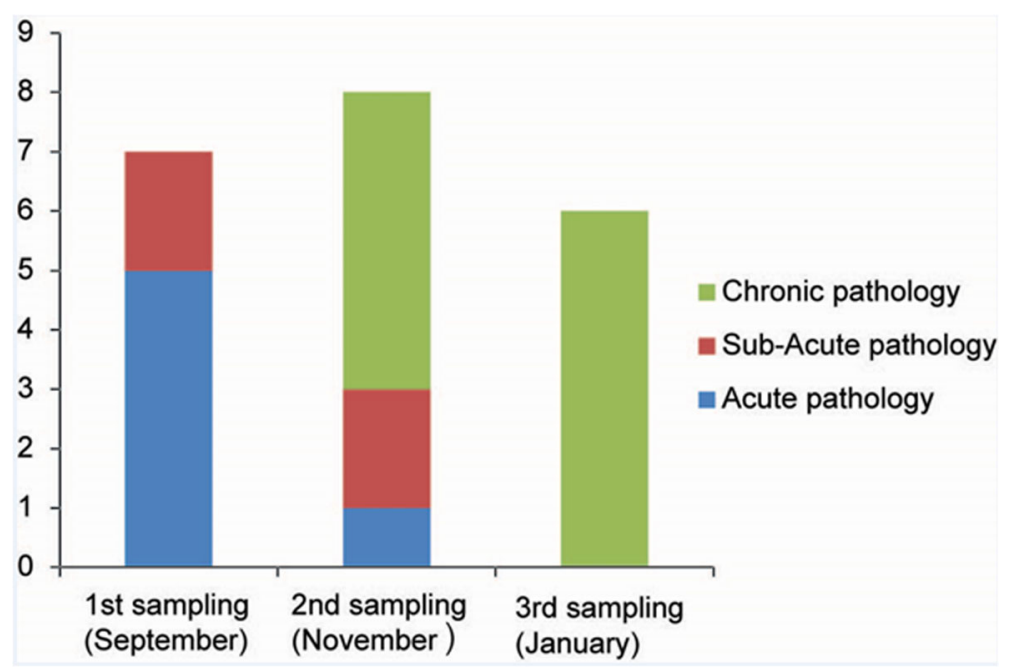

Fig. 3 Number of fish with acute, sub-acute or chronic histopathology at the three different sampling time points. The acute stage had much necrotic gill lesions with numerous $D$. lepeophtherii that were also systemically disseminated. The sub-acute is an intermediate stage defined by many foamy macrophages and little necrosis with $D$. lepeophtherii, but also with features in common with chronic stage as gill epithelial proliferation and granulomatous inflammation. The chronic group were separated from the sub-acute group by the presence of reparative changes like fibrin and collagen deposits in the granulomatous peritonitis and more gill epithelial proliferation 
chronic groups compared to the acute group, but a few necrotic foci with more $D$. lepeophtherii were occasionally found. The complex pathology in both acute and chronic features, suggest a persistent infection or reinfections that triggers the chronic inflammation. Proliferation of inter-lamellar gill epithelium increased from very sparse in the acute to a filling of the inter-lamellar space that could be complete in the chronic group. No pathology suggesting other known salmonid diseases, including IPN, were found.

\section{Histopathological details relating to acute, sub-acute and chronic stage disease \\ Acute stage}

In acute stages the gill epithelium was severely infected and appeared "dotted" due to widespread necrosis, swollen cells and morphologically different stages of $D$. lepeophtherii. Clusters of very small $D$. lepeophtherii spores in swollen cells were poorly stained, slightly iridescent in HE sections (Fig. 2a), but strongly fluorescent by both FCP (Fig. 2b) and CFW (Fig. 2c). Proliferative stages of $D$. lepeophtherii formed many cytoplasmic and some intra-nuclear, roundish, variably-sized pink bodies discernible on HE due to a clear halo (Fig. 2a and e), while strongly stained with ISH (Fig. $2 \mathrm{~d}$ and f). Focal necrosis and micro-vesicles containing debris and various microsporidian stages were variably stained by the in situ methods (Fig. 2d, f and "). The host response appeared limited to some infiltrating, often swollen, infected macrophages. Infected epithelial cells were involved in some lamellar adhesions (Fig. 2a), but the inter-lamellar spaces were largely intact as the gill epithelium had not proliferated, but moderately thickened due to swollen, infected cells. No other pathogens were found except for a few epitheliocysts superficially in the lamellar epithelium of three fish. As expected, all six fish had few well-organised granulomas around vacuoles with intraperitoneally injected oil adjuvant vaccine which is common for farmed Atlantic salmon. In addition four fish had a diffuse, acute peritonitis with necrosis and severe $D$. lepeophtherii infection as described for gill epithelium except that the intra-nuclear $D$. lepeophtherii stage was not observed (Fig. 4). In the two most severe cases, the peritonitis was partly continuous with similar lesions within the adherent GI-walls of stomach, pyloric ceca and hind gut segments. The severity of these

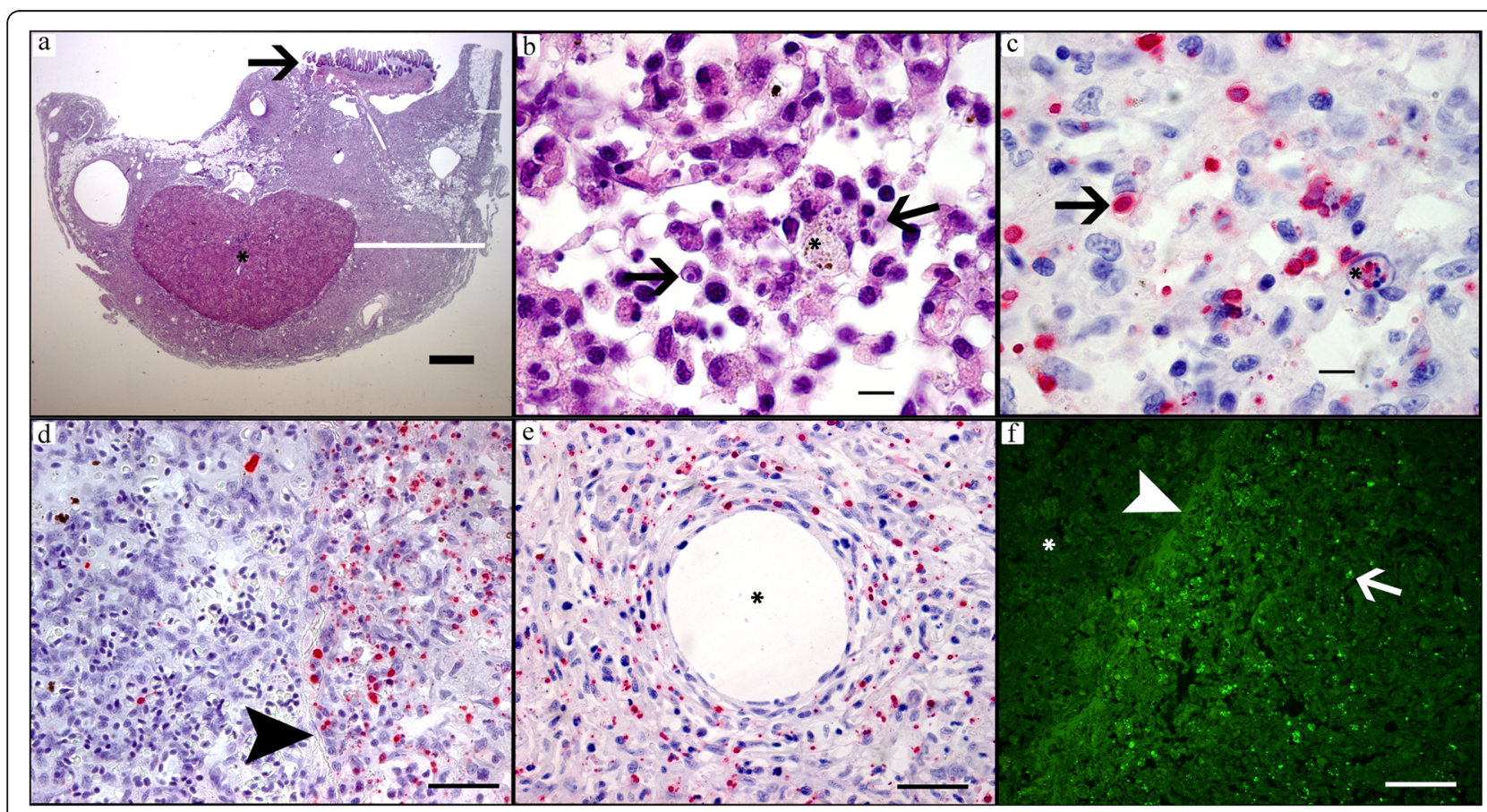

Fig. 4 Abdominal cavity with spleen and severe D. lepeophtherii infection in both a diffuse acute peritonitis and chronic vaccine related lesions. a HE-stain, spleen $\left(^{*}\right)$ and intestine (arrow) and perivisceral inflammatory tissue (white bar). b-f show details of a: $\mathbf{b}$ HE-stain of perivisceral inflammatory tissue with necrosis and iridescent spores $\left(^{*}\right)$ and pink proliferative stages of $D$. lepeophtherii surrounded by a halo (arrows). $\mathbf{c}$ ISH of same area as $\mathbf{b}$ showing proliferative stages of $D$. lepeophtherii stained red (arrow) including in a necrotic cell $\left(^{*}\right)$. $\mathbf{d}$ ISH staining proliferative stages of $D$. lepeophtherii red in the border area of spleen and perivisceral inflammatory tissue, many in the peritonitis, a few in the spleen, arrowhead pointing at the spleen capsule. e ISH staining proliferative stages of D. lepeophtherii red both in the diffuse peritonitis and in the organized, circular encapsulation of a droplet $\left(^{*}\right)$, presumably vaccine in oil-adjuvant. f FCP of border area of spleen and perivisceral inflammatory tissue showing green fluorescent $D$. lepeophtherii spores (arrow) especially in the peritonitis, while the spleen (*) appear less infected borderline between spleen and peritoneum (arrowhead). Scale-bars: a, $1 \mathrm{~mm} ; \mathbf{b}, \mathbf{c}, 10 \mu \mathrm{m} ; \mathbf{d}-\mathbf{f}, 50 \mu \mathrm{m}$ 
lesions diminished towards GI-lumen, often appearing to stop at the stratum compactum. In the lamina propria there was in general a diffusely distributed, sparse cytoplasmic infection and focal necrosis with no apparent link to the peritonitis. In the two most severely infected fish, widespread intra-nuclear infection of the gut epithelium out-numbered by far this $D$. lepeophtherii stage in the gill epithelium (Fig. $5 \mathrm{a}$ and b). Necrotic and degenerate cells often enlarged with spores or proliferative stages were found especially in the spleen stroma, kidney interstitial and endothelial cells of the heart bulbus arteriosus (data not shown). The infected cells appeared to be macrophages, endothelial and lymphopoietic or hematopoietic cells. Some infected cells found intravascularly suggested a hematogenic spread of $D$. lepeophtherii. The livers had some degenerative changes that could not be related directly to the $D$. lepeophtherii infection, but some focal necrosis and infections with $D$. lepeophtherii were observed in and around vessel walls. In the skin, a few necrotic dermal cells with halo surrounding the proliferative stages stained by ISH were observed in one fish only. The number of melanomacrophages appeared slightly or moderately increased in many tissues.

\section{Sub-acute stage}

The sub-acute stage was dominated with substantial host cellular response and lower levels of visible $D$. lepeophtherii. On autopsy two fish (A2 and A5) had "cheese-like" tissue in the abdomen and kidney that consisted of masses of foamy macrophages, sometimes multinucleated. The peritonitis appeared "invasive" extending deep into adjacent GI-walls destroying the muscular layers, stratum compactum and sometimes also the lamina propria while the epithelium was mostly unaffected (Fig. 6a). Two of these fish had large infiltrations of foamy macrophages in organs including spleen, kidney (Fig. 6b), heart (Fig. 6c), liver (Fig. 6d), gill and dermis of the skin. The hearts had extensive epi- and endocarditis with many foamy macrophages and eosinophilic granular cells. The liver had severe vasculitis with foamy macrophages. Two other fish with sub-acute disease had less infiltration with foamy macrophages and more visible stages of $D$. lepeophtherii. Erythrophagocytosis and variable hemosiderosis were seen in the spleens. In the gills there was some necrosis as in the acute stage, but also proliferation of epithelium that often filled about half of the inter-lamellar space. Other pathogens found in the gills were limited to a few

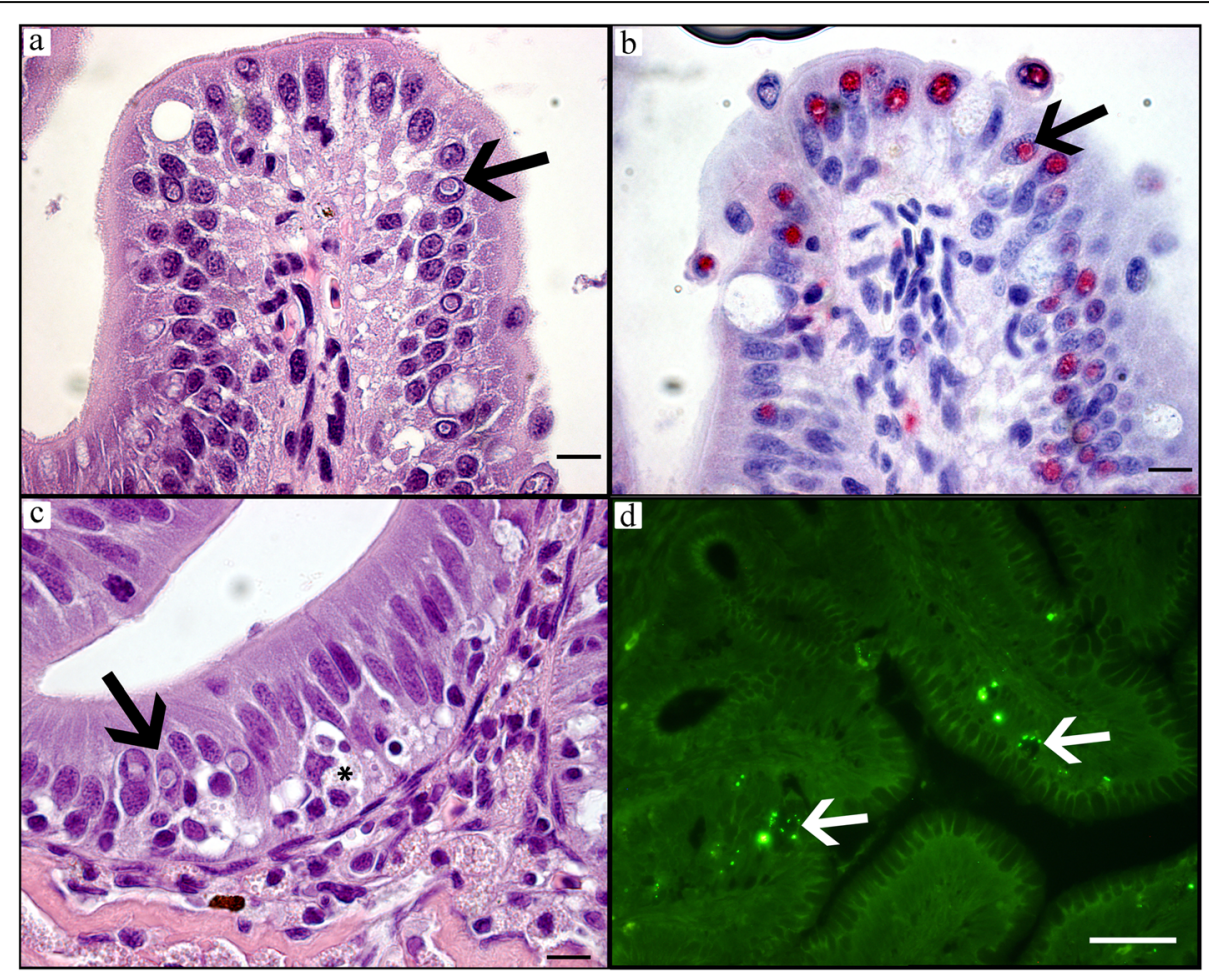

Fig. 5 Desmozoon lepeophtherii infection of the gastro-intestinal tract. a HE-stain, many intranuclear proliferative stages surrounded by a halo (arrow) in hind gut epithelium. $\mathbf{b}$ ISH of same hind gut area as in (a) with the intranuclear proliferative stages stained red (arrow). $\mathbf{c}$ HE-stain of pyloric ceca epithelium with necrosis $(*)$ and intranuclear proliferative stages surrounded by a halo (arrow). $\mathbf{d}$ FCP showing green fluorescent D. lepeophtherii spore clusters (arrows) in the stomach epithelium. Scale-bars: a-c, $10 \mu \mathrm{m} ; \mathbf{d}, 50 \mu \mathrm{m}$ 


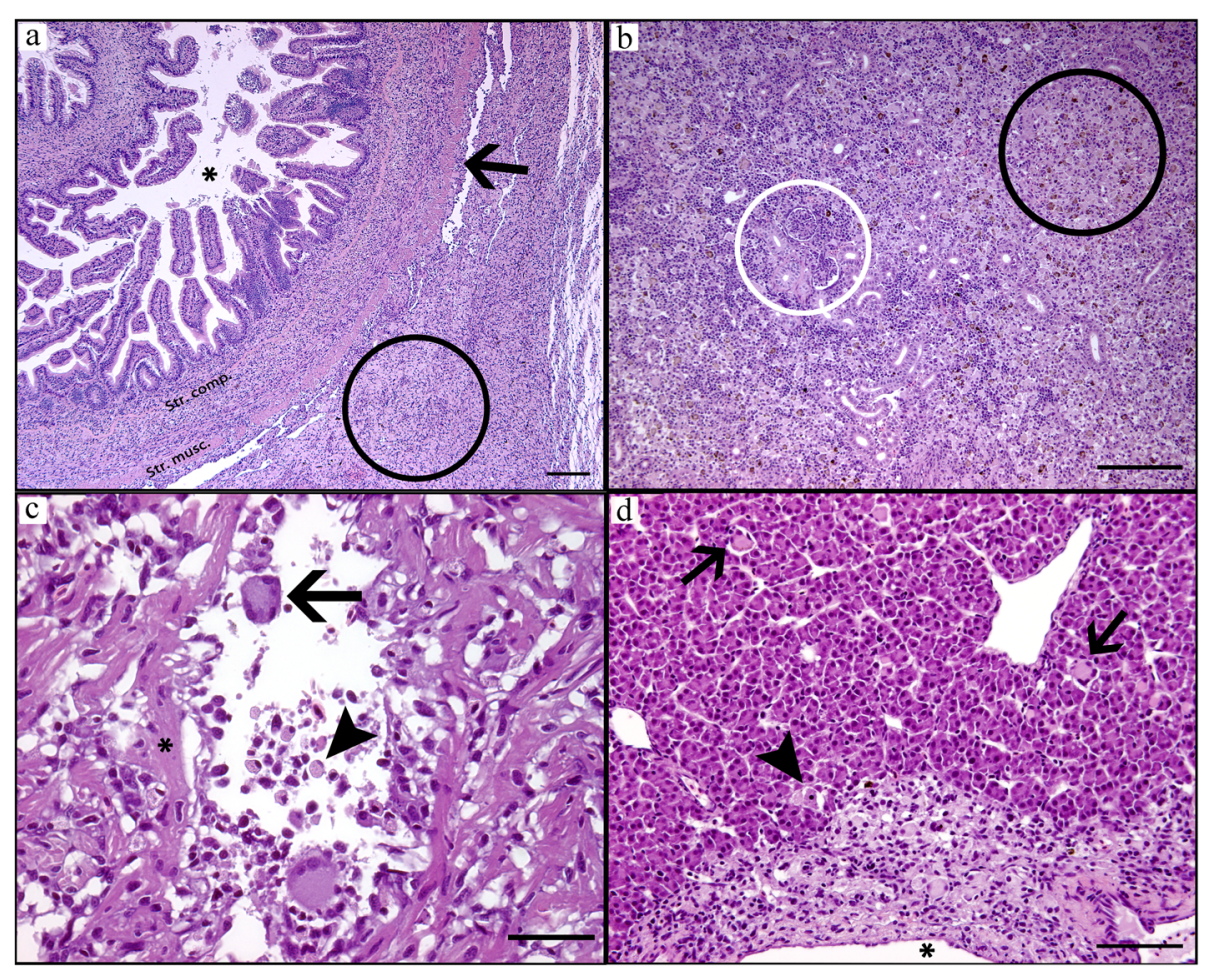

Fig. 6 Sub-acute pathology with foamy macrophage infiltration in hind gut, peritoneum, kidney, heart and liver. a HE-stain of hind gut with lumen $\left({ }^{*}\right)$, serosa (arrow) and peritonitis (circle) dominated by large foamy macrophages that also infiltrate the gut wall as deep as the stratum compactum, $\mathbf{b}$ HEstain of kidney with foamy macrophages (black circle) largely replacing the normal tissue (white circle). c HE-stain of heart lumen with foamy macrophages, including large multinucleated giant cells (arrow), eosinophilic granular cells (arrowhead) and endocarditis with some degenerative muscle changes (*). d HE-stain of liver, vasculitis with many foamy macrophages, lumen of vessel $\left(^{*}\right)$ at bottom of picture, in the liver parenchyma foamy giant cells (arrows) and some necrosis (arrowhead). Scale-bars: a, $200 \mu \mathrm{m} ; \mathbf{b}, \mathbf{d}, 100 \mu \mathrm{m} ; \mathbf{c}, 50 \mu \mathrm{m}$

epitheliocysts in one fish, and some Trichodina spp. ciliates in another fish.

\section{Chronic stage}

This stage revealed extensive proliferation of the gill epithelium in 5 fish (Fig. 7a) and granulomatous inflammation and fibrosis (Fig. 7b) in the abdomen of all fish. As in the acute and subacute groups the peritonitis appeared invasive into the GI-walls, but now more granulomatous and giant cells could be found destroying GI-wall elements (Fig. 7c). In proliferative gill (Fig. 7d), abdominal (Fig. 7e) and intestinal (Fig. 7f) lesions, moderate numbers $D$. lepeophtherii were visible. However, in general there were very sparse numbers $D$. lepeophtherii in the chronic lesions, occasional small foci of $D$. lepeophtherii infection with necrosis were encountered. In the fish with no or sparse $D$. lepeophtherii infection there was also little gill pathology. An intra-nuclear infection of the gut epithelium was only found in one fish, and apparently not associated with the "invasive" peritonitis. Other organs had only sparse to moderate inflammation dominated by macrophages, sometimes foamy, and often also some melanomacrophages. The hearts had consistently a sparse to moderate epi- and endocarditis. In the kidney and especially the spleen, some erythrophagocytosis and hemosiderosis were also found. In the liver only a sparse, diffuse distribution of melanomacrophages was common, except in one fish with multiple, zonal parenchymal liver necrosis (C2). This fish also had another gill infection; Tenacibaculum-like bacteria were found in distal necrosis of some adjacent filaments. Notably, polymorphic leukocytes and circulatory disturbances including haemorrhages were associated with the Tenacibaculum-like bacteria. The other parts of these gills had extensive proliferation of the gill epithelium with a moderate to severe $D$. lepeophtherii infection. Other visible gill pathogens were limited to a few Trichodina spp. and superficial epitheliocysts as in the acute and sub-acute groups, but the prevalence appeared higher as this was a finding in all fish of the chronic group.

\section{Discussion}

Previous studies have used PCR and histopathological examination to show the prevalence of $D$. lepeophtherii and its association with gill disease in Norwegian and Scottish Atlantic salmon farms $[29,35]$. The paucity of histopathology information about $D$. lepeophtherii infections is probably due to the difficulty of detecting poorly 


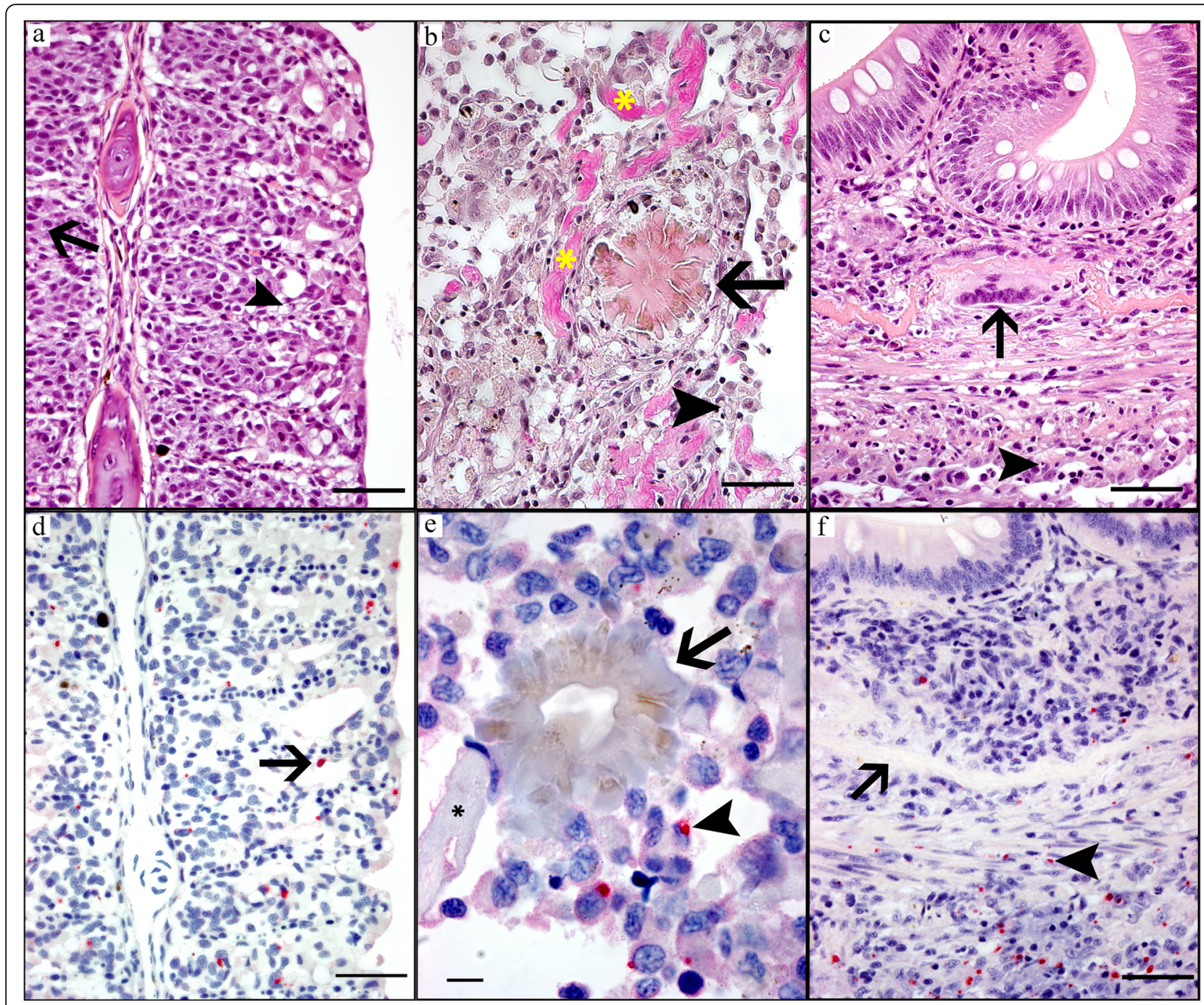

Fig. $7 \mathrm{HE}$, van Gieson and ISH stained sections showing chronic pathology in gill, peritoneum and intestine. a HE-stain of gill with extensive epithelial proliferation filling the space between lamellas and some cytoplasmic D. lepeophtherii proliferative stages surrounded by halo (arrow) and necrosis (arrowhead). $\mathbf{b}$ van Gieson-stain of granulomatous inflammation and fibrosis in the abdomen staining collagen deposits red (yellow *), D. lepeophtherii cytoplasmic proliferative stage (arrowhead) and Splendore-Hoeppli concrement (arrow). c HE-stain of invasive peritonitis in GI-wall, including D. lepeophtheri cytoplasmic proliferative stage (arrowhead) and multinucleated giant cell (arrow). d ISH of same area as in a showing proliferative stages of D. lepeophtherii stained red (arrow) in proliferative gill lesions, e ISH of same peritoneal area as in $\mathbf{b}$ showing proliferative stages of D. lepeophtherii stained red (arrowhead) and Splendore-Hoeppli concrement (arrow). $\mathbf{f} \mid \mathrm{SH}$ of same intestine as in $\mathbf{c}$ showing proliferative stages of D. lepeophtherii stained red (arrowhead) and stratum compactum (arrow). Scale-bars: a-d, f, $50 \mu \mathrm{m} ; \mathbf{e}, 10 \mu \mathrm{m}$

staining, minute spores and nondescript, pleomorphic proliferative stages in tissue sections. In the present study, we have addressed the lack of suitable in situ methods to detect $D$. lepeophtherii by using a combination of histopathology, CFW, FCP and ISH, to describe the disease progression. PCR method was used to confirm $D$. lepeophtherii infections. We used in situ methods for visualization of the D. lepeophtherii stages in association with severe tissue damage, and established a direct relationship between the parasite and observed pathology. Since experimental models are currently lacking, we examined a natural disease outbreak in farmed
Atlantic salmon and chose a case where the $D$. lepeophtherii infection appeared to be dominant.

We have shown for the first time, replication of $D$. lepeophtherii in the gut epithelium which could be a major source of dissemination of spores to the environment. This suggests that the infection dynamics of $D$. lepeophtherii may be more complex than previously assumed [27, 29]. Generalized and severe infection was observed in clinically diseased fish. The gills and the abdominal cavity seemed to be predilection sites for $D$. lepeophtherii replication that resulted in necrosis and damage to cells including macrophages. Thus, in the 
acute pathology stages the link between infection and pathology was obvious. In the sub-acute and chronic stages, infection levels in tissue sections were much lower with sparse focal and necrotic lesions. The tissues were also dominated by host responses, including macrophage infiltration, chronic peritonitis and gill hyperplasia. While the initial pathology seems to be caused by $D$. lepeophtherii proliferation, the late pathology may have been due to the severe host responses. This was reflected by change in the gills from the acute necrotic lesions to chronic proliferation of gill epithelium. In the abdomen, micro-vesicles were not formed as surrounding, intact multilayered epithelial tissue are needed to form the vesicle wall. However, necrosis and the halo proliferative stages of $D$. lepeophtherii were evident in the acute stages, and $D$. lepeophtherii infection was confirmed by in situ staining. In contrast, the chronic stage $D$. lepeophtherii pathology in the abdomen was not obvious.

Farmed Norwegian Atlantic salmon are vaccinated intraperitoneally with an oil-adjuvant vaccine before sea-water transfer. Desmoozon lepeophtherii infect macrophages [29], which could migrate to inflammatory foci like vaccine-induced granulomas and then infect the same lesions. Thus, any granulomatous inflammation due to $D$. lepeophtherii would be additional granulomas to the preexisting granulomatous vaccine side-reaction. This may result in co-localization of D. lepeophtherii infection and vaccine side-reactions. A characteristic that could distinguish the D. lepeophtherii related inflammation was the invasiveness deep into the gastrointestinal muscular walls not expected by an inert, killed vaccine. Moreover, this increasing granulomatous inflammation came at a time when vaccine side-effects are expected to decrease. Thus, in cases of stunted growth and unexpected vaccine sidereactions it would be pertinent to investigate if $D$. lepeophtherii could be involved.

In this study, several methods were chosen to diagnose D. lepeophtherii since no single method stains both spores and proliferative stages. The spore staining was chosen as it targeted an inherent trait of the spores: the chitinous endospore wall. The quickest and most generally applicable method was the calcofluor method. The broad specificity is ideal for an initial investigation to uncover all agents with a chitinous wall, including fungi. Although morphology may indicate pathogen identity, sequencing rRNA gene would be necessary to identify these at the species level. The spores can also be stained by Gram [35] or Luna [36], but this will not give any information on the presence of a chitinous spore wall. The fluorescein chitin probe (FCP) is chemically more specific for chitin and yields permanent slides easier to read than CFW. Both CFW and FCP worked well to demonstrate spores in this study, but presently the commercial reagent for FCP utilizing the chitin binding protein of Bacillus circulans as probe seems unavailable. These findings correlate with previous reports of high binding affinity and detection of chitin cell walls [37, 38]. A different method was necessary to stain the proliferative stages before spore formation. Since these stages are metabolically active with many ribosomes, we developed an ISH targeting rRNA sequences. The specificity of the probe was confirmed by the use of the sense probe. This procedure allowed a specific diagnosis of $D$. lepeophtherii infection and evaluation of the pathological lesions on the same sections from paraffin embedded tissue by ordinary light microscopy. This method clearly showed that most of the pathology was linked to the proliferative stages of $D$. lepeophtherii and that the halo surrounded bodies on HE sections were indeed $D$. lepeophtherii. Although our procedure was excellent to explore the relationship between the D. lepeophtherii and the pathology, simpler procedures, e.g. FISH and using DNA probes could be more practical for routine diagnostic purposes.

Real-time PCR was undoubtedly the most sensitive and specific way to detect the $D$. lepeophtherii infections. The results showed that the in situ methods are less sensitive and that PCR is the method of choice to just determine the presence of the agent. Real-time PCR can also be quantitative or semi-quantitative, but if rRNA was targeted the Ct-values would reflect the number of ribosomes and not individual D. lepeophtherii organisms. Spores that are metabolically inactive would contribute little to the Ct-values. We targeted the ribosomal gene, so the Ct-values can reflect the gene, including those in spores. Unfortunately, as our samples for PCR were taken in various ways for general diagnostics, it was not possible to follow the $D$. lepeophtherii infection by PCR systematically over time in specific organs. Nevertheless, the results indicate that acute stages with generalized infection and necrotic lesions with many $D$. lepeophtherii spores present could be associated with Ct-values in the lower range. However, looking at the in situ methods it appears that infection could be very unevenly distributed between organs and variable over the course of the disease. This suggests that PCR data from the disease stages with localized rather than generalized infection should be interpreted with caution. Thus, it remains to be known how a best sample can be obtained for PCR especially in the chronic stages of $D$. lepeophtherii-related disease. Further, PCR data would always benefit from being interpreted in the light of pathology investigations, and here these suggest that the sensitized host may respond with severe chronic inflammation to even low infection levels.

We used the term acute pathology in the description of the necrotic lesions with little host response and severe $D$. lepeophtherii infection. However, this high level 
of infection may have developed over time prior to the disease level found on our first sampling. We do not know why this level of infection had built up, but the clinical disease history and our findings may provide some clues. Although not causing problems, sea-lice were present and source of the D. lepeophtherii infection. On the first sampling we found the highest level of $D$. lepeophtherii intranuclear infection in the intestine of emaciated fish due to the freshwater IPN outbreak. This intra-nuclear stage of $D$. lepeophtherii gives rise to the resistant spores released to the environment. Gill and skin epithelium have earlier been reported as the cell type shedding spores [10, 29]. However, the intra-nuclear intestinal infection was more severe than in gill or skin tissue, suggesting that the gut can be very important for the dissemination of $D$. lepeophtherii. The large number of fish in close confinement in a sea-water salmon farm environment may facilitate a fecal-oral transmission route other microsporidia are known to exploit [39]. In other intra-nuclear fish microsporidia, Nucleospora salmonis [25, 40] and Enterospora nucleophila [41], the gut is involved. Clearly the complex life-cycles and diseases linked to $D$. lepeophtherii need to be explored further. The economic loss was significant in this disease outbreak due to a moderate mortality, and more importantly, the severely stunted growth of many fish. It is noteworthy that most gill diseases are multifactorial and resolving the roles of a growing number of infectious agents will require extensive experimental and epidemiological investigations. We hope that the methods and observations from this case study of a D. lepeophtherii infection will contribute to this process.

\section{Conclusions}

The economic impact of gill disease to Atlantic salmon farms annually is huge. Desmozoon lepeophtherii has previously been found to be associated with gill disease in Atlantic salmon. However, information about the pathology associated to different stages of the parasite over the course of infection is limited. Here we used different in situ diagnostic method to associate the proliferative stages of $D$. lepeophtherii with necrosis in the acutely diseased fish. In chronically diseased fish with stunted growth we report lower levels of infection associated with severe inflammatory reactions, which revealed the importance of host responses to the pathology. We also described intranuclear infection of the gut epithelium, which implicated the gut for the first time as a source of D. lepeophtherii spore shedding to the environment. Our results provide evidence in favour of combining different diagnostic tools to better understand disease pathology in fish.

\section{Abbreviations}

CFW: Calcofluor-white; CMS: Cardiomyopathy syndrome;

DEPC: Diethylpyrocarbonate; FCP: Fluorescent chitin probe;

Gl: Gastrointestinal: HE. Hematoxylin and eosin: HSMI: Heart and skeletal

muscle inflammation; IBD-CC: Inflammatory bowel disease - colon cancer-like disease; IPN: Infectious pancreatic necrosis; ISH: In situ hybridization; PD: Pancreas disease; PGI: Proliferative gill inflammation

\section{Acknowledgement}

The authors wish to thank Randi Terland and her staff at the NVI histology laboratory for excellent quality of tissue sections.

\section{Funding}

This work was funded through Norwegian Veterinary Institute internal project entitled "Strategic Institute Program (SIP)"- Modern tools for investigations of disease pathogenesis.

\section{Availability of data and materials}

All data generated or analyzed during this study are included in the article. Paraffin embedded tissue and RNAlater materials from all organs used for the work are deposited at the Norwegian Veterinary Institute archive and are available to the public

\section{Authors' contributions}

SCW carried out the laboratory investigation and drafted and edited the paper, OBD diagnosed the case, carried out the histopathological investigation and edited the paper, $\mathrm{HH}$ performed and analyzed real time PCR result and edited the paper, MCG drafted the paper and worked out the bibliography, LBR carried out clinical investigations and KF conceived, revised and edited the paper. All authors read and approved the final manuscript.

Ethics approval and consent to participate

Not applicable.

Consent for publication

Not applicable.

\section{Competing interests}

The authors declare that they have no competing interests.

\section{Publisher's Note}

Springer Nature remains neutral with regard to jurisdictional claims in published maps and institutional affiliations.

\section{Author details}

${ }^{1}$ Norwegian Veterinary Institute, P.O.Box 750 Dep., N-0106 Oslo, Norway. ${ }^{2}$ Present address: Fiske-liv AS, Marine Harvest Apotekergt. 9A, 6004 Alesund, Norway.

Received: 16 January 2017 Accepted: 20 July 2017

Published online: 02 August 2017

References

1. FAO. The State of World Fisheries and Aquaculture 2014 E-ISBN 978-92-5108276-8. http://www.fao.org/3/a-i3720e.pdf.

2. Norwegian Veterinary Institute fish Health Report. 2015. https://www.vetinst. no/rapporter-og-publikasjoner/rapporter/2016/fish-health-report-2015.

3. Koppang EO, Bjerkås I, Haugarvoll E, Chan EK, Szabo NJ, Ono N, et al. Vaccinationinduced systemic autoimmunity in farmed Atlantic salmon. J Immunol. 2008;181:4807-14

4. Dale OB, Tørud B, Kvellestad A, Koppang HS, Koppang EO. From chronic feedinduced intestinal inflammation to adenocarcinoma with metastases in salmonid fish. Cancer Res. 2009:69:4355-62.

5. Mitchell SO, Rodger HD. A review of infectious gill disease in marine salmonid fish. J Fish Dis. 2011;34(6):411-32.

6. Steinum T, Kvellestad A, Colquhoun DJ, Heum M, Mohammad S, Grøntvedt $\mathrm{RN}$, et al. Microbial and pathological findings in farmed Atlantic salmon Salmo salar with proliferative gill inflammation. Dis Aquat Org. 2010;91:201-11.

7. Gjessing MC, Yutin N, Tengs T, Senkevich T, Koonin E, Rønning HP, et al. Salmon gill poxvirus, the deepest representative of the Chordopoxvirinae. J Virol. 2015:89:11174.

8. Steinum T, Kvellestad A, Rønneberg LB, Nilsen $\mathrm{H}$, Asheim A, Fjell $\mathrm{K}$, et al. First cases of amoebic gill disease (AGD) in Norwegian seawater farmed Atlantic salmon, Salmo salar L., and phylogeny of the causative amoeba using 18S cDNA sequences. Fish Dis. 2008;31:205-14. 
9. Nylund A, Watanabe K, Nylund S, Karlsen M, Sæther PA, Arnesen CE, et al. Morphogenesis of salmonid gill poxvirus associated with proliferative gill disease in farmed Atlantic salmon (Salmo salar) in Norway. Arch Virol. 2008; 153:1299-309.

10. Nylund S, Andersen L, Saevareid I, Plarre H, Watanabe K, Arnesen CE, et al. Diseases of farmed Atlantic salmon Salmo salar associated with infections by the microsporidian Paranucleospora theridion. Dis Aquat Org. 2011:94:41-57.

11. Draghi A 2nd, Popov VL, Kahl MM, Stanton JB, Brown CC, Tsongalis GJ, et al. Characterization of "Candidatus Piscichlamydia salmonis" (order Chlamydiales), a chlamydia-like bacterium associated with epitheliocystis in farmed Atlantic salmon (Salmo salar). J Clin Microbiol. 2004;42:5286-97.

12. Karlsen M, Nylund A, Watanabe K, Helvik JV, Nylund S, Plarre H. Characterization of 'Candidatus Clavochlamydia salmonicola': an intracellular bacterium infecting salmonid fish. Environ Microbiol. 2008;10:208-18.

13. Kvellestad A, Falk K, Nygaard SM, Flesja K, Holm JA. Atlantic salmon paramyxovirus (ASPV) infection contributes to proliferative gill inflammation (PGI) in seawater-reared Salmo salar. Dis Aquat Org. 2005;67:47-54.

14. Keeling PJ, Fast NM. Microsporidia: biology and evolution of highly reduced intracellular parasites. Annu Rev Microbiol. 2002;56:93-116.

15. Müller A, Bialek R, Kämper A, Fätkenheuer G, Salzberger B, Franzen C. Detection of microsporidia in travelers with diarrhea. J Clin Microbiol. 2001;39:1630-2.

16. Mathis A, Weber R, Deplazes P. Zoonotic potential of the microsporidia. Clin Microbiol Rev. 2005;18(3):423-5.

17. Didier ES. Microsporidiosis: an emerging and opportunistic infection in humans and animals. Acta Trop. 2005;94:61-6.

18. Cislakova L, Halanova M. Microsporidial infections in immunocompromised hospitalised patients. Epidemiol Mikrobiol Imunol. 2003;52:81-3.

19. Kent ML, Speare DJ. Review of the sequential development of Loma salmonae (Microsporidia) based on experimental infections of rainbow trout (Oncorhynchus mykiss) and Chinook salmon (O. tshawytscha). Folia Parasitol. 2005:52:63-8.

20. Kent ML. Marine net pen farming leads to infections with some unusual parasites. Int J Parasitol. 2000;30:321-6.

21. Cali A, Weiss LM, Takvorian PM. A review of the development of two types of human skeletal muscle infections from microsporidia associated with pathology in invertebrates and cold-blooded vertebrates. Folia Parasitol. 2005;52:51-61.

22. Freeman MA, Kasper JM, Kristmundsson Á. Nucleospora cyclopteri n. sp., an intranuclear microsporidian infecting wild lumpfish, Cyclopterus lumpus L., in Icelandic waters. Parasit Vectors. 2013;6:49.

23. Rodríguez-Tovar LE, Wright GM, Wadowska DW, Speare DJ, Markham RJ. Ultrastructural study of the early development and localization of Loma salmonae in the gills of experimentally infected rainbow trout. J Parasitol. 2002;88:244-53.

24. Sánchez JG, Speare DJ, Markham RJ, Wright GM, Kibenge FS. Localization of the initial developmental stages of Loma salmonae in rainbow trout (Oncorhynchus mykiss). Vet Pathol. 2001;38:540-6.

25. Grésoviac SJ, Baxa DV, Vivarès CP, Hedrick RP. Detection of the intranuclear microsporidium Nucleospora salmonis in naturally and experimentally exposed Chinook salmon Oncorhynchus tshawytscha by in situ hybridization. Parasitol Res. 2007;101:1257-64.

26. Freeman MA, Sommerville C. Desmozoon lepeophtherii n. gen., n. sp., (Microsporidia: Enterocytozoonidae) infecting the salmon louse Lepeophtheirus salmonis (Copepoda: Caligidae). Parasit Vectors. 2009;2:58.

27. Freeman MA, Sommerville C. Original observations of Desmozoon lepeophtherii, a microsporidian hyperparasite infecting the salmon louse Lepeophtheirus salmonis, and its subsequent detection by other researchers. Parasit Vectors. 2011;4:231

28. Freeman MA, Bell AS, Sommerville CA. A hyperparasitic microsporidian infecting the salmon louse, Lepeophtheirus salmonis: an rDNA-based molecular phylogenetic study. J Fish Dis. 2003;26(11-12):667-76.

29. Nylund S, Nylund A, Watanabe K, Arnesen CE, Karlsbakk E. Paranucleospora theridion n. gen., n. sp. (Microsporidia, Enterocytozoonidae) with a life cycle in the salmon louse (Lepeophtheirus salmonis, Copepoda) and Atlantic salmon (Salmo salar). J Eukaryot Microbiol. 2010;57:95-114.

30. Bancroft JD, Stevens A. Theory and practice of histogical techniques. 4th ed. Edinburg: Churchill Livingstone; 1996.

31. Monheit JE, Cowan DF, Moore DG. Rapid detection of fungi in tissues using calcofluor white and fluorescence micro copy. Arch Pathol Lab Med. 1984;108:616-8.
32. Stine SW, Vladich FD, Pepper IL, Gerba CP. Development of a method for the concentration and recovery of microsporidia from tap water. J Environ Sci Health A Tox Hazard Subst Environ Eng. 2005;40:913-25.

33. Watanabe $T$, Ito $Y$, Yamada $T$, Hashimoto $M$, Sekine $S$, Tanaka $H$. The roles of the C-terminal domain and type III domains of chitinase A1 from Bacillus circulans WL-12 in chitin degradation. J Bacteriol. 1994;176:4465-72.

34. Solstad T, Stenvik J, Jørgensen TO. mRNA expression patterns of the BPI/LBP molecule in the Atlantic cod (Gadus morhua L.). Fish Shellfish Immunol. 2007;23:260-71.

35. Matthews CG, Richards RH, Shinn AP, Cox DI. Gill pathology in Scottish farmed Atlantic salmon, Salmo salar L., associated with the microsporidian Desmozoon lepeophtherii Freeman et Sommerville, 2009. J Fish Dis. 2013; 36:861-9.

36. Peterson TS, Spitsbergen JM, Feist SW, Kent ML. Luna stain, an improved selective stain for detection of microsporidian spores in histologic sections. Dis Aquat Org. 2011;95:175-80.

37. Hashimoto M, Ikegami T, Seino S, Ohuchi N, Fukada H, Sugiyama J, et al. Expression and characterization of the chitin-binding domain of chitinase A1 from Bacillus circulans WL-12. J Bacteriol. 2000;182:3045-54.

38. Hardt M, Laine RA. Mutation of active site residues in the chitin-binding domain ChBDChiA1 from chitinase A1 of Bacillus circulans alters substrate specificity: use of a green fluorescent protein binding assay. Arch Biochem Biophys. 2004;426:286-97.

39. Stentiford GD, Becnel JJ, Weiss LM, Keeling PJ, Didier ES, Williams BA, et al. Microsporidia - emergent pathogens in the global food chain. Trends Parasitol. 2016;32:336-48.

40. El Alaoui H, Grésoviac SJ, Vivarès CP. Occurrence of the microsporidian parasite Nucleospora salmonis in four species of salmonids from the Massif Central of France. Folia Parasitol. 2006:53:37-43.

41. Palenzuela O, Redondo MJ, Cali A, Takvorian PM, Alonso-Naveiro M, AlvarezPellitero $P$, et al. A new intranuclear microsporidium, Enterospora nucleophila n. sp., causing an emaciative syndrome in a piscine host (Sparus aurata), prompts the redescription of the family Enterocytozoonidae. Int J Parasitol. 2014:44:189-203.

\section{Submit your next manuscript to BioMed Central and we will help you at every step:}

- We accept pre-submission inquiries

- Our selector tool helps you to find the most relevant journal

- We provide round the clock customer support

- Convenient online submission

- Thorough peer review

- Inclusion in PubMed and all major indexing services

- Maximum visibility for your research

Submit your manuscript at www.biomedcentral.com/submit 